\title{
Relationship between the Demographic Characteristics of Park Users and Park Based User Activities: The Case of Stanley Park and Queen Elizabeth Park
}

\section{Takyi SA*}

University of Northern British Columbia, Canada

*Corresponding author: Stephen Appiah Takyi, University of Northern British Columbia, Address: 120-3000 15th Avenue, Canada, Tel: 7788900412; E-mail: drtakyi410@gmail.com
Research Article

Volume 1 Issue 2

Received Date: July 10, 2017

Published Date: July 22, 2017

DOI: $10.23880 /$ jenr-16000107

\section{Abstract}

The changing roles of urban parks to cover a wider range of functions have made the study of the park use and user characteristics necessary for the advancement of knowledge and contribution to policy decisions. This research examines the relationship between the demographic characteristics of park users and park based user activities. A survey was conducted to collect the requisite data for this research. A total of 374 and 351 park users were interviewed in Stanley Park and Queen Elizabeth Park respectively. The study showed that active park activities such as jogging and biking is mostly influenced by age and gender with the younger age group category dominating in these activities. On the other hand passive park activity such as enjoying scenery is mostly dominated by the adult population. The study further showed that most park users use Stanley Park and Queen Elizabeth Park for their recreational activities because of ecological benefits such as connection to nature, access to fresh air and aesthetics from the natural environment.

Keywords: Demographic; Parks; Relationship; Activities

\section{Background}

Hayward and Weitzer [1] describe urban parks as a unique setting within the urban landscape that provides space for physical activities, social interaction and nature conservation. The contemporary use of urban parks has moved beyond recreation and pleasure to help attain broader sustainability goals. The attainment of sustainable city development can only be realized if the functional roles of cities effectively cover economic development, social progress and environmental protection. The development of urban parks is crucial towards the achievement of the complex goal of achieving sustainability in our cities.
Parks and recreation services have now become one of the largest sources of expenditures for many municipalities and regional districts, and are often heavily subsidized by property tax revenues [2]. The importance of parks in our cities is clearly justified by the high level of investment in its development and management. Garvin and Berens justify the investments in the development of parks by arguing that judicious public spending on park development stimulates widespread and sustained private investment, alters settlement patterns, encourages social interaction and reshapes the very character of daily life [3]. 


\section{Journal of Ecology \& Natural Resources}

Gress $\mathrm{M}$ also points out that the distribution of parks promotes overall public health through the provision of space for physical activity as well as social interaction [4]. Chiesura notes that less scientific and political attention is being paid to the type of nature close to where people live and work and their benefits to urban dwellers compared to other issues such as crime and the economy [5]. There is therefore the need for researchers to study park use and user characteristics which have implications for park planning and management.

Park users could be classified as either direct or indirect users. Direct park users are those who use the physical space of the park for active recreation and other social activities. Indirect park users, on the other hand, benefit from the existence of parks without directly using the physical space. The indirect park benefits are mostly in the form of environmental and aesthetic benefits. Some of the indirect environmental benefits of parks include purification of the air by the greeneries on the park through the absorption of carbon dioxide and the release of oxygen.

Kitchen and Hendon also classify the economic benefits of urban parks into primary and secondary benefits. The primary benefits are those which accrue directly to the user while the indirect benefits are the impacts of the primary benefits resulting from recreational development such as increase in taxes [6]. The creation of parks either for environmental, social or economic purposes are human centered. This is because the benefits derived from the park go a long way to improve the living conditions of city dwellers either being direct or indirect. The study of park use and user characteristics will help in understanding the preferences of park users; thus, providing the intellectual basis for urban park policy formulation and management. The value cities place on urban parks depend on the intensity of park use which can only be ascertained through the analysis of park use and user characteristics. The changing roles of urban parks to cover a wider range of functions have made the study of the park use and user characteristics necessary for the advancement of knowledge and contribution to policy decisions. There is, therefore, the need for park administrators and policy makers to understand how the demographic characteristics of park users influence park activities. This will help improve existing park literature and also inform park management strategies and decision making processes.

McCormack et al. note that many characteristics of urban parks have been linked to the pattern of physical activity. The study of park use and user characteristics helps in understanding the user preferences thus providing the intellectual basis for urban park policy formulation and management. The development of urban parks is mostly influenced by factors such as demographic characteristics of park users, type of park activities and the pattern of activities. This research will contribute immensely to urban park literature by assessing how demographic characteristics influence specific park activities.

Bish and Clemens observe that parks and recreation services have now become one of the largest sources of expenditures for many municipalities and regional districts, and are often heavily subsidized by property tax revenues [2]. The importance of parks in our cities is justified by the high level of investment in their development and management. The level of investment in the development of parks is mostly based on the values city authorities and residents place on parks. Therefore, the level of investment in the development of parks varies from city to city. Garvin and Berens justify the investments in the development of parks by arguing that judicious public spending on park development stimulates widespread and sustained private investment, alters settlement patterns, encourages social interaction and reshapes the very character of daily life [3].

Overall, the growing interest in the development of parks has not influenced the level of research on park systems and green space development. Chiesura argues that less scientific and political attention is being paid to the type of nature close to where people live and work and their benefits to urban dwellers compared to other issues such as crime and the economy [5]. Therefore, there is the need for researchers to study park use and user characteristics which have implications for park planning and management. Park users could be classified as either direct or indirect users. Direct park users are those who use the physical space of the park for active recreation and other social activities. Indirect park users, on the other hand, benefit from the existence of parks without directly using the physical space. The indirect park benefits are mostly in the form of environmental and aesthetic benefits. Some of the indirect environmental benefits of parks include purification of the air by the greeneries on the park through the absorption of carbon dioxide and the release of oxygen. Kitchen and Hendon on the other hand classified the economic benefits of urban parks into primary and secondary benefits. The primary benefits are those which accrue directly to the user while the indirect benefits are the impacts of the primary 
benefits resulting from recreational development such as increase in taxes [6]. The creation of parks either for environmental, social or economic purposes are human centered. This is because the benefits derived from the park go a long way to improve the living conditions of city dwellers either being direct or indirect.

\section{Urban Park Usage and Benefits}

The provision of urban parks within cities rests largely on professional assumptions about its significance on the lives of residents [7]. These professional assumptions are based on intensive research on park use and the characteristics of the users. The social and cultural values of urban parks according to Thompson include attitudes towards nature and the desire to be in contact with it [8]. An urban park can create a sense of place, a landmark and a community focal point which may increase property values and create incentives for development [3].

Park spaces play multiple roles in making cities more sustainable and these include ecological, social and economic benefits [9]. The true value of urban parks can be assessed and the justification for their development can only be made through a critical analysis of these benefits. The multifunctional nature of parks has necessitated the need for the involvement of wide range of interest groups in their planning and management. Gobster notes that urban park user groups for large cities can be very heterogeneous thus the need to understand and respond to their diverse needs [10].

The development of parks as a means of preserving land in cities is an effective way of benefiting from future increases in the value of land. The aesthetics of a neighbourhood can be improved through the provision of parks, thus helping to increase the real estate values of such neighbourhoods. Real estate surveys according to Home et al. indicate that natural open spaces with walking and biking paths are among the top four most desirable features in a residential neighbourhood. Urban parks and other green spaces in close proximity to housing can reduce residential heating and cooling costs by $12 \%$ on the average [11].

The benefits of urban parks make their study relevant to societal wellbeing and academic progress. The multidimensional nature of the use and management of urban parks makes their planning process more complex, as the interest of all the diverse stakeholders should be considered in the urban park policy formulation process. There is constant conflict between the economic use of urban land for private sector development and the environmental interest of using these limited land resources for urban park development. The consideration of these interests during the formulation and implementation of urban park development policies makes the process more complicated, costly and time consuming and sometimes adversely affects the protection of the natural environment in our cities. The benefits derived from the use of urban parks could be discussed from the ecological, social and economic perspectives.

\section{Contemporary Urban Park Use and Ecological Benefits}

According to Bowler, urban greening has been proposed as one approach to mitigate the human health consequences of increased temperatures resulting from climate change. Urban parks help in maintaining the biodiversity of the urban environment [12]. Alvey argues that preserving biodiversity should also be an important goal in the urban environment, especially in highly urbanized areas where little natural habitats remain [13]. Parks provide many ecosystem benefits, such as regulating ambient temperatures, filtering air, reducing noise, sequestering carbon and absorbing storm-water [9]. The presence of parks in urban areas has a lot of medical benefits thus making their uses relevant to medical disciplines such as psychology and human biology. The possible benefits of contact with nature according to environmental psychologists, indicates that human contact with nature is fundamental for human health and well-being [14]. These benefits of urban parks indicate the multi-dimensional benefits derived from the use of parks. This implies that the findings of park research go beyond social sciences to include disciplines and interest groups within physical sciences. This makes urban parks research not only a multi stakeholder study but also a multidisciplinary study.

\section{Contemporary Urban Park Use and Social Benefits}

Local parks and playgrounds according to Bish and Clemens are generally open to all citizens without restrictions thus depicting characteristics of a public good [2]. The social benefits derived from the use of urban parks ranges from recreational purposes to serving as a focal point for communal engagement and social interactions. Home et al. note that public involvement in the creation of parks can be an entry point to community engagement and social change. The social benefits accrued from the use of parks include providing space for 


\section{Journal of Ecology \& Natural Resources}

social interactions which helps in connecting neighbours around a common social goal.

Parks offer urban residents solace from their stressful lives, hasten recovery from disease or illness, and can foster active living [9]. The development of parks helps to promote community identity and social interaction in our cities. Nature settings often enhance social interactions, which in turn can help foster a sense of community [14]. However, urban parks especially the abandoned ones have many security implications that make it necessary to involve security experts in their planning and management to help minimize the incidence of crime on these parks. The potential for these spaces to be a source of major fire outbreak within the city during the dry and summer seasons also make it very important to involve the fire department in the planning and management of urban parks. These also justify the multidisciplinary and multi-stakeholder nature of the planning and management of urban parks.

\section{Contemporary Urban Park Use and Economic Benefits}

The future economic benefits of urban parks manifest in the long run through the adaptation of the city's anticipated impacts of climate change such as higher temperatures, increased flooding and increased storminess [9]. The availability of parks also promotes the aesthetics of the city. This helps in improving the overall quality of life in cities, which attracts tourism and other economic activities of great interest to policy makers, politicians and economist. The continuous increase in the population of urban centres leads to an increase in the demand for land which also contributes to the increase in land values. Real estate research shows that 78 percent of all home buyers in the United States rated open space as very important. Garvin and Berens also note that property values of Manhattan doubled during the 15 years after park development began [3].

The long term economic benefits of urban parks make it difficult for city authorities and policy makers to preserve urban lands for parks development. This is because, there is a high demand for land in urban centres leading to competing land uses in the short term. Nowak and Dwyer argue that inadequate understanding of the wide range of benefits, costs and expected outcome of urban green space management options can reduce the contribution of the greeneries towards improving urban environments and quality of life [15]. The benefits of urban parks have necessitated the need for extensive research to help link the various benefits and interest groups in a way that will provide theoretical direction for urban park literature and development.

\section{Summary of Literature and Emerging Issues}

The continuous increase in the demand for green spaces in cities has contributed immensely to the development of parks. Urban parks have multiple benefits thus making it economically, socially and environmentally beneficial to city residents. Van Dyck, et al. point out those public parks are important settings for the promotion of social activities and environmental conservation in cities. Park researchers such as Kitchen and Hendon, Burgess et al., Thompson, Garvin and Berens, Home et al. and Byrne and Sipe have done extensive studies on the benefits of parks [3,6-9,11]. These studies showed the multifunctional nature of parks and how parks help in increasing property values. There are also several studies on how the demographic characteristics of park users influence the use of parks. McCormack, et al. and Van Dyck et al. for instance studied how the urban neighbourhood characteristics influence physical activities on parks.

There is however limited literature in the area of assessing the relationship between the demographic characteristics of park users and specific park activities such as jogging and walking. This justifies the need to study how the demographic characteristics of park user influence specific park activities such as biking, enjoying scenery and playing field sports. Conducting such studies can help park administrators and policy makers to meet the diverse needs of park users thus stimulating park use and user activities. Van Dyck, et al. notes that the increase in park use and activity levels can be facilitated by defining the attributes related to active park use.

\section{Research Questions}

The overall goal of this aspect of the study is to assess the relationship between the demographic characteristics of park users and park based user activities. The following research questions have been formulated in order to help achieve this goal:

- What is the relationship between park activities in Stanley and Queen Elizabeth Park and the demographic characteristics of park users?

- Are there implications for future park development and management? 


\section{Journal of Ecology \& Natural Resources}

\section{Research Hypothesis}

The following hypothesis will be tested based on 95 percent confidence interval. This implies that if the Pvalue is less than 0.05 , then there is a statistically significant relationship between the demographic characteristics of park users and park based user activities.

- Ho: There is no relationship between the demographic characteristics of park users and the activities they undertake at the parks.

- Ha: There is a relationship between the demographic characteristics of park users and the activities they undertake at the parks.

\section{Description of Case Studies}

The research was undertaken at the City of Vancouver in the province of British Columbia. The City of Vancouver was highly convenient for this study because of its proximity and cost effectiveness. The city is currently noted for its ambitious plan to become the world's most sustainable city thus formulating policies to protect its natural environment including its green spaces. The research focused on the two major parks in the City of Vancouver namely Stanley Park and Queen Elizabeth Park.

\section{Research Method}

The design and evaluation of questionnaires and of other written and oral materials is a challenging endeavour, fraught with potential pitfalls [16]. A structured questionnaire was used to interview park users. This helped in identifying the various categories of park uses and users, their demographic characteristics, park users' opinion on park funding and recommendations to improve park services. Structured interviews follow a predetermined and standardized list of questions with the questions asked almost in the same way and order in each interview [17].

The wording and components of the questionnaire was an important and critical component of the study. The precise wording of questions played a vital role in determining the answers given by the respondents [18]. The questionnaire for the survey consisted of the age of respondents, gender, income, employment, place of origin (the place park users came from), reason for choice of park and the number of people accompanying interview respondents. The impact of personal bias on the design of questionnaire was minimized through the use of different research lenses to evaluate the questionnaire before using it for the survey. Gendall argues that all questionnaires reflect the designer's view of the world, no matter how objective the researcher has attempted to be. Intellectually, good questionnaire designers understand this and attempt to maintain a detached objectivity.

The survey was conducted in Stanley Park and Queen Elizabeth Park. Stanley Park was selected because it is a good representation of large parks while Queen Elizabeth Park represents medium size parks. The users of each park were interviewed in the month of August, 2014 from $8 \mathrm{am}$ to $5 \mathrm{pm}$. The survey for each park was done over a period of one week. The data collection took place from Monday to Sunday for each park.

\section{Total Number of Questionnaires-Sample Size}

According to Vaske, survey research involves administrating questionnaires to a sample of respondents selected from a larger population. Samples are normally used in surveys due to time and financial limitations. Samples are used for making inferences about the population of interest. In this case, the sample was used to make inferences about the total number of park users of Stanley Park and Queen Elizabeth Park [19].

Vaske argues that it is desirable for most parks, recreation, and human dimensions studies to obtain enough completed questionnaires to allow the researcher to be $95 \%$ confident that estimates from the data are within $\pm 5 \%$ (or points) of the sample population. The survey results for example showed that $53.46 \%$ of the sampled users of Stanley Park were married; we can therefore be $95 \%$ confident that between $48.46 \%$ and $58.46 \%$ of all park users are married [19].

The total number of questionnaires used for this study was calculated using Salant \& Dillman's formula for estimating the desired sample sizes. This formula comprises of all the variables that address Vaske questions of obtaining large sample size for a survey. Payne used this formula for developing the Resource Guide for Community Survey Projects [19]. The resource guide was developed to provide instructions and guidance for community parks and recreation staff in the process of conducting a community needs assessment and/or evaluation [20]. The formula used for calculating the sample size is:

Ns $=(N p)(p)(1-p) /(N p-1)(B / C) 2+(p)(1-p)$

Ns $=$ Sample size needed

$\mathrm{Np}=$ Size of population (total number of park users for Stanley Park and Queen Elizabeth Park) 


\section{Journal of Ecology \& Natural Resources}

$\mathrm{p}=$ Proportion expected to answer a certain way $(50 \%$ or 0.5 is most conservative)

$\mathrm{B}=$ Acceptable level of sampling error $(0.05= \pm 5 \%$ meaning there is $95 \%$ chance that the possible error for a result is $\pm 5 \%$ of the result obtained by the questionnaire.)
$\mathrm{C}=\mathrm{Z}$ statistic associate with confidence interval $(1.960=$ 95\% confidence level)

The resulting sampling size and response rate of the survey is shown in (Table 1).

\begin{tabular}{|c|c|c|c|c|}
\hline Name of Park & $\begin{array}{c}\text { Number } \\
\text { of Users Per Year }\end{array}$ & Sample Size & $\begin{array}{c}\text { Total Survey } \\
\text { Respondents }\end{array}$ & $\begin{array}{c}\text { Response } \\
\text { Rate }\end{array}$ \\
\hline Stanley Park & $8,000,000$ & 384 & 374 & $97.40 \%$ \\
\hline Queen Elizabeth Park & $6,000,000$ & 384 & 351 & $91.40 \%$ \\
\hline
\end{tabular}

Table 1: Total Number of Questionnaires.

\section{Data Analysis}

Data collected was analysed based on the major research themes. These research themes were broadly categorised into the demographic characteristics of the park users and the various park based user activities. The analysis of the park user characteristics specifically dealt with the demographic characteristics of the park users which include the gender of the users, their employment status, age and income. Data entry, analysis and statistical tests were done using Microsoft excel and Stata software (version 12) were used for the analysis of data and the various statistical tests.

The bivariate analysis was used in testing the relationship between the demographic characteristics of park users and the various park activities. The relationship between the demographic characteristics of park users and park based activities was tested using the chi-squared analysis. The P-Values were calculated and the significance level is $\mathrm{P} \leq 0.05$. Generally, the smaller the P-Value, the stronger the evidence against the null hypothesis provided by the data.

\section{Results of the Study-Demographic Characteristics of Park Visitors and Park Based User Activities}

The relationship between the demographic characteristics of park users and the type of park activities plays a significant role in shaping the activity levels of parks [21]. These analytical results serve as the basis for park administrators and all relevant stakeholders to improve park activities based on the specific demographic characteristics of the park users. The findings of this part of the study will help park administrators and city authorities to develop more focused recreational programs and facilities. Mowen et al. note that despite the fact that theoretical evidence illustrates the importance of the environmental variables in the promotion of park use; there is limited research on the role of demographic characteristics in relation to different levels and types of park based activities [21].

Cohen et al. describe public parks as important facilities which provide spaces for individuals to play, ride bicycles, walk, jog and undertake a variety of other recreational activities. This chapter presents an analysis of the relationship between the demographic characteristics of the park visitors and the various park based activities in Stanley Park and Queen Elizabeth Park. The statistical tests for the relationship between the demographic characteristics of the park users and park based activities were done using the Chi-squared analysis [22].

\section{Demographic Characteristics of Park Users and the Use of Stanley Park and Queen Elizabeth Park for Jogging}

The chi-square analysis indicated that there is enough evidence to reject the null hypothesis $\left(\mathrm{H}_{\mathrm{o}}\right.$ : there is no relationship between marital status, gender, place of origin, race, age and the use of Stanley Park for jogging) at 95\% confidence interval. There is therefore a statistically significant relationship between marital status, gender, place of origin, race, age and the use of Stanley Park for jogging $(\mathrm{P} \leq 0.05)$.

Jogging is an important park activity that requires a lot of physical strength. The survey results indicated that park users who are single, divorced or widowed (19.05\%) jog more often than park users who are married $(10.36 \%)$. Also, the statistical analysis showed that males are more likely to jog on Stanley Park than females. Relatively, more males (19.35\%) often jog on Stanley Park compared to females $(8.84 \%)$. The results further showed 


\section{Journal of Ecology \& Natural Resources}

that while $30.65 \%$ sometimes use Stanley Park for jogging, it is $19.89 \%$ among females. Additionally, $50 \%$ of male never use Stanley Park for jogging while is less than $71 \%$ among females.

In terms of place of origin, park visitors from Vancouver are more likely to use Stanley Park for jogging than park visitors who came from outside Canada. The statistical test indicated that $47.44 \%$ of park users from Vancouver often jog on Stanley Park compared to $67.94 \%$ of park users who visited the park from outside Canada. Overall, the statistical test showed that the younger age group are more likely to jog on Stanley Park than the older age group. The statistical analysis indicated that $15.45 \%$ of park users under the age of 30 years often jog on Stanley Park compared to $14.56 \%$ among park users who are 40 years and above. Also, 37.27\% of park users below the age of 30 years sometimes jog on Stanley Park whilst it is $12.66 \%$ among park users above the age of 40 years.

The survey results further indicated that ethnic minority groups such as Asians and Blacks are more likely to jog on Stanley Park than Whites. The study indicated that $51.20 \%$ of ethnic minority groups never use Stanley Park for jogging compared to $64.52 \%$ of Whites. Additionally, $34.40 \%$ of ethnic minority sometimes uses Stanley Park for jogging while it is $20.97 \%$ among Whites. Park policies and management decisions targeted at improving jogging on Stanley Park must therefore take into consideration the marital status, the place of origin, race and age of the park users.

Finally, the chi-square analysis showed that there is no statistically significant relationship between employment, religion, income and the use of Stanley Park for jogging $(\mathrm{P}>0.05)$. There is not enough evidence to reject the null $\left(\mathrm{H}_{\mathrm{o}}\right.$ : There is no relationship between the demographic characteristics such as employment, religion and income status of park users and jogging on Stanley Park) at 95\% confidence interval. Thus, park management decision concerning jogging on Stanley Park will be minimally influenced by employment, religion and income status of park users.
The chi-square analysis suggested that there is no statistically significant relationship between employment, marital status, place of origin, race, religion, income and the use of Queen Elizabeth Park for active jogging $(\mathrm{P}>0.5)$. This implies that there is not enough evidence to reject the null hypothesis $\left(\mathrm{H}_{\mathrm{o}}\right.$ : there is no relationship between employment, marital status, place of origin, race, religion, income and the use of Queen Elizabeth Park for active jogging) at 95\% confidence interval.

However, the statistical analysis showed a significant relationship between gender, age and active jogging on Queen Elizabeth Park $(\mathrm{P} \leq 0.05)$. The survey results indicated that males are more likely to jog on Queen Elizabeth Park than females. While $37.57 \%$ of males sometimes jog on Queen Elizabeth Park, it is 22.89\% among females. Also, 54.14\% of males never use Queen Elizabeth Park for jogging compared to $68.07 \%$ of females.

Furthermore, park users below the age of 30 years are more likely to jog on Queen Elizabeth Park than park users above the age of 40 years. The study showed that twice the number of Queen Elizabeth park users below the age of 30 years jog more often than park users above the age of 40 years. Also, among the park users who never jog on Queen Elizabeth Park, 53.85\% are below the age of 30 years whilst $73.47 \%$ are above the age of 40 years. Additionally, $36.15 \%$ of park users below the age of 30 years sometimes use Queen Elizabeth Park for jogging compared to $21.09 \%$ of the park users above the age of 40 years.

Similar to the findings of Stanley Park, the younger age group among Queen Elizabeth Park users are more likely to use the park for jogging than the older age group. Demographic characteristics such as age and gender are therefore important determinants of park based activities such as jogging which requires a lot of physical strength. The statistical analysis of the relationship between the demographic characteristics and jogging has been presented in (Table 2).

\begin{tabular}{|c|c|c|c|c|c|c|c|c|}
\hline \multirow{2}{*}{$\begin{array}{c}\text { Demographic } \\
\text { Characteristics }\end{array}$} & $\begin{array}{c}\text { Never } \\
\text { (\%) }\end{array}$ & $\begin{array}{c}\text { Sometimes } \\
\text { (\%) }\end{array}$ & $\begin{array}{c}\text { Often } \\
\text { (\%) }\end{array}$ & P-Value & $\begin{array}{c}\text { Never } \\
\text { (\%) }\end{array}$ & $\begin{array}{c}\text { Sometimes } \\
\text { (\%) }\end{array}$ & $\begin{array}{c}\text { Often } \\
\text { (\%) }\end{array}$ & P-Value \\
\hline $\begin{array}{c}\text { Employment } \\
\text { Full Time }\end{array}$ & 57.82 & 26.07 & 16.11 & 0.480 & 58.08 & 31.74 & 10.18 & 0.470 \\
Others & 63.17 & 24.54 & 12.27 & & 63.39 & 29.51 & 7.10 & \\
\hline
\end{tabular}

Takyi SA. Relationship between the Demographic Characteristics of Park Users and Park Based User Activities: The Case of Stanley Park and Queen Elizabeth Park. J Ecol \& Nat Resources 2017, 1(2): 000107. 


\section{Journal of Ecology \& Natural Resources}

\begin{tabular}{|c|c|c|c|c|c|c|c|c|}
\hline $\begin{array}{c}\begin{array}{c}\text { Marital Status } \\
\text { Married }\end{array} \\
\text { Other }\end{array}$ & $\begin{array}{l}68.91 \\
50.00\end{array}$ & $\begin{array}{l}20.73 \\
30.95\end{array}$ & $\begin{array}{l}10.36 \\
19.05\end{array}$ & 0.001 & $\begin{array}{l}66.01 \\
56.85\end{array}$ & $\begin{array}{l}26.80 \\
33.50\end{array}$ & $\begin{array}{l}7.19 \\
9.64\end{array}$ & 0.217 \\
\hline $\begin{array}{c}\begin{array}{c}\text { Gender } \\
\text { Male }\end{array} \\
\text { Female } \\
\end{array}$ & $\begin{array}{l}50.00 \\
71.27\end{array}$ & $\begin{array}{c}30.65 \\
19.89\end{array}$ & $\begin{array}{l}19.35 \\
8.84\end{array}$ & 0.000 & $\begin{array}{l}54.14 \\
68.07\end{array}$ & $\begin{array}{l}37.57 \\
22.89\end{array}$ & $\begin{array}{l}8.29 \\
9.04\end{array}$ & 0.012 \\
\hline $\begin{array}{l}\begin{array}{c}\text { Place of Origin } \\
\text { Vancouver }\end{array} \\
\text { Within Canada } \\
\text { Outside Canada }\end{array}$ & $\begin{array}{r}47.44 \\
72.04 \\
67.94 \\
\end{array}$ & $\begin{array}{l}29.49 \\
23.26 \\
21.27 \\
\end{array}$ & $\begin{array}{r}23.08 \\
4.65 \\
10.69 \\
\end{array}$ & 0.000 & $\begin{array}{l}57.86 \\
70.27 \\
75.00 \\
\end{array}$ & $\begin{array}{l}32.14 \\
24.32 \\
25.00 \\
\end{array}$ & $\begin{array}{l}10.00 \\
5.41 \\
0.00 \\
\end{array}$ & 0.144 \\
\hline $\begin{array}{c}\text { Race } \\
\text { White } \\
\text { Ethnic Minority }\end{array}$ & $\begin{array}{r}64.52 \\
51.20\end{array}$ & $\begin{array}{l}20.97 \\
34.40\end{array}$ & $\begin{array}{l}14.52 \\
14.40\end{array}$ & 0.015 & $\begin{array}{l}60.75 \\
60.74\end{array}$ & $\begin{array}{l}32.26 \\
28.83\end{array}$ & $\begin{array}{r}6.99 \\
10.43\end{array}$ & 0.466 \\
\hline $\begin{array}{c}\text { Religion } \\
\text { Christians } \\
\text { Other Religion } \\
\text { No Religion } \\
\end{array}$ & $\begin{array}{l}65.03 \\
67.57 \\
53.29\end{array}$ & $\begin{array}{l}21.86 \\
24.32 \\
30.26\end{array}$ & $\begin{array}{l}13.11 \\
8.11 \\
16.45\end{array}$ & 0.183 & $\begin{array}{l}63.56 \\
58.70 \\
60.00\end{array}$ & $\begin{array}{l}27.97 \\
30.43 \\
31.89\end{array}$ & $\begin{array}{l}8.47 \\
10.87 \\
8.11\end{array}$ & 0.926 \\
\hline $\begin{array}{c}\text { Income } \\
\text { Under } \$ 50,000 \\
\\
\text { Above } \$ 50,000\end{array}$ & $\begin{array}{r}62.30 \\
59.13 \\
\end{array}$ & $\begin{array}{l}27.05 \\
24.60 \\
\end{array}$ & $\begin{array}{l}10.66 \\
16.27 \\
\end{array}$ & 0.346 & $\begin{array}{r}65.28 \\
57.77 \\
\end{array}$ & $\begin{array}{l}28.47 \\
32.04 \\
\end{array}$ & $\begin{array}{r}6.25 \\
10.19 \\
\end{array}$ & 0.262 \\
\hline $\begin{array}{c}\text { Age } \\
\text { Under } 30 \\
\\
30-40 \\
\text { Over } 40 \\
\end{array}$ & $\begin{array}{r}47.27 \\
55.77 \\
72.78 \\
\end{array}$ & $\begin{array}{r}37.27 \\
30.77 \\
12.66 \\
\end{array}$ & $\begin{array}{l}15.45 \\
13.46 \\
14.56 \\
\end{array}$ & 0.000 & $\begin{array}{r}53.85 \\
47.95 \\
73.47 \\
\end{array}$ & $\begin{array}{l}36.15 \\
39.73 \\
21.09 \\
\end{array}$ & $\begin{array}{l}10.00 \\
12.33 \\
5.44 \\
\end{array}$ & 0.001 \\
\hline
\end{tabular}

Table 2: Relationship between Demographic Characteristics of Park Users and Jogging

${ }^{*} \mathrm{H}_{\mathrm{o}}$ : There is no relationship between the demographic characteristics park users and active jogging.

${ }^{*}$ Ha: There is a relationship between the demographic characteristics park users and active jogging.

\section{Demographic Characteristics of Park Users and the use of Stanley Park and Queen Elizabeth Park for Biking}

Overall, the relationship between employment, marital status, gender, religion, income, age and biking on Stanley Park was not statistically significant $(P>0.05)$. Hence, there is not enough evidence to suggest that the null hypothesis $\left(\mathrm{H}_{\mathrm{o}}\right.$ : there is no relationship between employment, marital status, gender, religion, income, age and biking on Stanley Park) is false at 95\% confidence level. The chi-square analysis further showed that there is a statistically significant relationship between place of origin, race and the use of Stanley Park for biking $(\mathrm{P} \leq 0.05)$. The study revealed that park users from Vancouver are more likely to bike on Stanley Park than park users from outside Canada. The results showed that $26.28 \%$ of park visitors from Vancouver often bike on Stanley Park while it is less than $10 \%$ among the tourists from outside Canada.

Also, among the park users who never bike, 28.85\% were from Vancouver compared to $60.31 \%$ from outside Canada. Generally, park users who live in Vancouver have access to their own bicycles and other recreational 
equipment. These categories of users therefore do not have much constraint when it comes to accessibility to recreational equipment such as bicycles. During the field visits, the interactions with some of the tourists revealed that most of the tourists do not have adequate information on where to rent recreational equipment such as bicycles. It is also costly for these tourists to travel with their recreational equipment thus limiting their ability to participate in active sports such as biking. Park administrators and managers must therefore improve the information flow on the rental options for bicycles for tourist. With regard to race, the statistical test showed that it is more likely for ethnic minority groups such as Blacks and Asians to bike on Stanley Park than Whites. The survey results indicated that ethnic minority $(16.80 \%)$ which include Asians and Blacks bike more often than Whites (15.78\%). Also, among the parks users who were Whites $52.42 \%$ never bike on Stanley Park while the ethnic minority groups constituted $37.60 \%$. In examining the relationships, the chi-square analysis showed a statistically significant relationship between marital status, gender, place of origin and the use of Queen Elizabeth Park for biking $(\mathrm{P} \leq 0.05)$.Consequently, there is enough evidence that the null hypothesis $\left(\mathrm{H}_{\mathrm{o}}\right.$ : there is no relationship between marital status, gender, place of origin and the use of Queen Elizabeth Park for biking) is false at $95 \%$ confidence level. The results showed that park users who are single, divorced or widowed are more likely to bike on Queen Elizabeth Park than park users who are married. The statistical analysis indicated that while $14.21 \%$ of park users who are single, divorced or widowed bike often on Queen Elizabeth Park, it is $6.26 \%$ among park users who are married. The survey results further indicated that males are more likely to bike on Queen Elizabeth Park than females. Relatively, more males (14.29\%) often bike on Queen Elizabeth Park compared to $7.23 \%$ among females. Also, the results showed that $52.75 \%$ of males never use the park for biking while it is less than $66 \%$ among females. Additionally, park users who visit the park from Vancouver are more likely to bike on Queen Elizabeth Park than park users from outside Canada. The study showed that $11.74 \%$ of park users from Vancouver often bike on Queen Elizabeth Park compared to 3.13\% of park user from outside Canada. Also, among the park users of Queen Elizabeth Park who never bike, 53.74\% were from Vancouver while $78.13 \%$ were from outside Canada.

These findings are consistent with that of Stanley Park; thus, indicating that indigenous park users bike more than tourist. Finally, the chi-square analysis indicated that there is no statistically significant relationship between employment, race, religion, income, age and biking on Queen Elizabeth Park ( $>0.05)$. The statistical analysis on the relationship between the demographic characteristics of Queen Elizabeth Park users and biking has been showed in (Table 3).

\begin{tabular}{|c|c|c|c|c|c|c|c|c|}
\hline \multirow{2}{*}{$\begin{array}{l}\text { Demographic } \\
\text { Characteristics }\end{array}$} & \multicolumn{4}{|c|}{ Stanley Park } & \multicolumn{4}{|c|}{ Queen Elizabeth Park } \\
\hline & $\begin{array}{c}\text { Never } \\
(\%)\end{array}$ & $\begin{array}{c}\text { Sometimes } \\
(\%)\end{array}$ & $\begin{array}{c}\text { Often } \\
(\%)\end{array}$ & P-Value & $\begin{array}{c}\text { Never } \\
(\%)\end{array}$ & $\begin{array}{c}\text { Sometimes } \\
(\%)\end{array}$ & $\begin{array}{c}\text { Often } \\
(\%)\end{array}$ & P-Value \\
\hline $\begin{array}{l}\text { Employment } \\
\text { Full Time }\end{array}$ & 45.02 & 36.97 & 18.01 & 0.422 & 52.69 & 34.73 & 12.57 & 0.074 \\
\hline Others & 50.31 & 36.20 & 13.50 & & 64.67 & 26.09 & 9.24 & \\
\hline $\begin{array}{c}\text { Marital Status } \\
\text { Married }\end{array}$ & 51.81 & 35.23 & 12.95 & 0.160 & 64.29 & 29.22 & 6.49 & 0.046 \\
\hline Other & 42.26 & 39.88 & 17.86 & & 54.82 & 30.96 & 14.21 & \\
\hline $\begin{array}{l}\text { Gender } \\
\text { Male }\end{array}$ & 43.55 & 39.78 & 16.67 & 0.234 & 52.75 & 32.97 & 14.29 & 0.025 \\
\hline Female & 51.93 & 32.04 & 16.02 & & 65.66 & 27.11 & 7.23 & \\
\hline $\begin{array}{l}\text { Place of Origin } \\
\text { Vancouver }\end{array}$ & 28.85 & 44.87 & 26.28 & & 53.74 & 34.52 & 11.74 & \\
\hline Within Canada & 61.63 & 30.23 & 8.14 & 0.000 & 81.08 & 8.11 & 10.81 & 0.002 \\
\hline Outside Canada & 60.31 & 30.53 & 9.16 & & 78.13 & 18.75 & 3.13 & \\
\hline
\end{tabular}

Takyi SA. Relationship between the Demographic Characteristics of Park Users and Park Based User Activities: The Case of Stanley Park and Queen Elizabeth Park. J Ecol \& Nat Resources 2017, 1(2): 000107. 
Journal of Ecology \& Natural Resources

\begin{tabular}{|c|c|c|c|c|c|c|c|c|}
\hline $\begin{array}{c}\text { Race } \\
\text { White } \\
\text { Ethnic Minority }\end{array}$ & $\begin{array}{l}52.42 \\
37.60\end{array}$ & $\begin{array}{l}31.85 \\
45.60\end{array}$ & $\begin{array}{l}15.73 \\
16.80\end{array}$ & 0.016 & $\begin{array}{r}60.96 \\
56.44\end{array}$ & $\begin{array}{l}28.34 \\
32.52\end{array}$ & $\begin{array}{l}10.70 \\
11.04\end{array}$ & 0.666 \\
\hline $\begin{array}{c}\text { Religion } \\
\text { Christians }\end{array}$ & 49.73 & 36.61 & 13.66 & & 63.03 & 23.53 & 13.45 & \\
\hline Other Religion & 48.65 & 32.43 & 18.92 & 0.742 & 58.70 & 30.43 & 10.87 & 0.319 \\
\hline No Religion & 44.08 & 38.16 & 17.76 & & 56.22 & 34.59 & 9.19 & \\
\hline $\begin{array}{c}\text { Income } \\
\text { Under } \mathbf{\$ 5 0 , 0 0 0}\end{array}$ & 50.00 & 31.97 & 18.03 & 0.407 & 58.33 & 30.56 & 11.11 & 0.977 \\
\hline Above $\$ 50,000$ & 46.03 & 38.89 & 15.08 & & 59.42 & 29.95 & 10.63 & \\
\hline $\begin{array}{c}\text { Age } \\
\text { Under } \mathbf{3 0}\end{array}$ & 40.00 & 42.73 & 17.27 & & 54.62 & 32.31 & 13.08 & \\
\hline $30-40$ & 43.27 & 39.42 & 17.31 & 0.107 & 52.05 & 31.51 & 16.44 & 0.070 \\
\hline Over 40 & 55.70 & 30.38 & 13.92 & & 66.22 & 27.70 & 6.08 & \\
\hline
\end{tabular}

Table 3: Relationship between Demographic Characteristics of Park Users and Biking

${ }^{*} \mathrm{H}_{\mathrm{o}}$ : There is no relationship between the demographic characteristics of park users and biking.

${ }^{*}$ Ha: There is a relationship between the demographic characteristics of park users and biking.

\section{Demographic Characteristics of Park Users and the use of Stanley Park and Queen Elizabeth Park for Active Field Sports}

In examining the relationships, the statistical tests showed a significant relationship between gender, place of origin, race, age and the use of Stanley Park for active field sports $(\mathrm{P} \leq 0.05)$. The results indicated that males are more likely to use Stanley Park for active field sports than females. The study showed that more males (4.84\%) often engage in active field sports on Stanley Park compared to $2.76 \%$ among females. Also, $74.73 \%$ of males never engage in active field sports on Stanley Park while it is $86.19 \%$ among females. The place of origin of park users is also an important determinant to the use of Stanley Park for active field sports. The users of Stanley Park coming from Vancouver who often engage in active field sports constitute $5.77 \%$ while those from outside Canada are $0.76 \%$. Also, park users coming from Vancouver who never engage in active field sports consist of $73.72 \%$ with those coming from outside Canada constituting $87.79 \%$.

Generally, tourists visit parks to enjoy facilities that cannot be easily accessed in their home countries or communities. This justifies why the participation of tourists in active field sports is minimal since these facilities are mostly accessible in their home countries. Park administrators must therefore develop unique facilities, activities and characteristics of parks in order to stimulate tourist attraction. The statistical test further showed that park users under the age of 30 years are more likely to use Stanley Park for active field sports than park users over the age of 40 years. The visitors of Stanley Park below the age of 30 years who often engage in active field sports were twice the number of park users who were above the age of 40 years. Overall, the finding of this study is showing a pattern where park activities that require more physical strength are dominated by the youthful population. Overall, the chi-square analysis showed that there is no statistically significant relationship between employment, marital status, religion, income and the use of Stanley Park for active field sports $(\mathrm{P}>0.05)$. Similar to the research findings of Stanley Park, the statistical analysis showed that demographic characteristics such as gender and age are important determinants in the use of Queen Elizabeth Park for active field sports. Statistically, there is a significant relationship between gender, age and the use of Queen Elizabeth Park for active field sport $(\mathrm{P} \leq 0.05)$. The results indicated that males are more likely to engage in active field sports on Queen Elizabeth Park than females. While $6.04 \%$ of males often engage in active field sports on the park, it is $2.41 \%$ among females. Also, $68.13 \%$ of males never engage in active field sports on 
Queen Elizabeth Park compared to $86.75 \%$ among females.

Similar to Stanley Park users, the survey results showed that park users under the age of 30 years are more likely to engage in active field sports on Queen Elizabeth Park than park users above the age of 40 years. Park users below the age of 30 years (6.15\%) engage in active field sports more often than the visitors of Queen Elizabeth Park above the age of 40 years $(2.03 \%)$. Additionally, among the users of Queen Elizabeth Park who never engage in active field sports, $70.00 \%$ were below the age of 30 years while $89.19 \%$ were above the age of 40 years.
The statistical analysis further showed that there is no statistically significant relationship between demographic characteristics such as employment, marital status, place of origin, race, religion, income and the use of Queen Elizabeth Park for active field sports $(\mathrm{P}>0.05)$. Therefore, there is not enough evidence to suggest that the null hypothesis $\left(\mathrm{H}_{\mathrm{o}}\right.$ : there is no relationship between employment, marital status, place of origin, race, religion, income and the use of Queen Elizabeth Park for active field sports) is false at $95 \%$ confidence level. The statistical analysis of the relationship between demographic characteristics and active field sports has been presented in (Table 4).

\begin{tabular}{|c|c|c|c|c|c|c|c|c|}
\hline \multirow[b]{2}{*}{$\begin{array}{l}\text { Demographic } \\
\text { Characteristics }\end{array}$} & \multicolumn{4}{|c|}{ Stanley Park } & \multicolumn{4}{|c|}{ Queen Elizabeth Park } \\
\hline & $\begin{array}{c}\text { Never } \\
(\%)\end{array}$ & $\begin{array}{c}\text { Sometimes } \\
\text { (\%) }\end{array}$ & $\begin{array}{c}\text { Often } \\
(\%)\end{array}$ & P-Value & $\begin{array}{c}\text { Never } \\
(\%)\end{array}$ & $\begin{array}{c}\text { Sometimes } \\
(\%)\end{array}$ & $\begin{array}{c}\text { Often } \\
(\%)\end{array}$ & P-Value \\
\hline $\begin{array}{l}\text { Employment } \\
\text { Full Time }\end{array}$ & 81.04 & 14.22 & 4.74 & 0.359 & 77.25 & 17.96 & 4.79 & 0.882 \\
\hline Others & 79.75 & 17.79 & 2.45 & & 77.17 & 19.02 & 3.80 & \\
\hline $\begin{array}{l}\text { Marital Status } \\
\text { Married }\end{array}$ & 83.94 & 11.92 & 4.15 & 0.129 & 83.12 & 13.64 & 3.25 & 0.066 \\
\hline Other & 76.79 & 19.64 & 3.57 & & 72.59 & 22.34 & 5.08 & \\
\hline $\begin{array}{c}\text { Gender } \\
\text { Male }\end{array}$ & 74.73 & 20.43 & 4.84 & 0.022 & 68.13 & 25.82 & 6.04 & 0.000 \\
\hline Female & 86.19 & 11.05 & 2.76 & & 86.75 & 10.84 & 2.41 & \\
\hline $\begin{array}{l}\text { Place of Origin } \\
\text { Vancouver }\end{array}$ & 73.72 & 20.51 & 5.77 & 0.030 & 74.38 & 20.64 & 4.98 & \\
\hline Within Canada & 81.40 & 13.95 & 4.65 & & 83.78 & 13.51 & 2.70 & 0.120 \\
\hline Outside Canada & 87.79 & 11.45 & 0.76 & & 93.75 & 6.25 & 0.00 & \\
\hline $\begin{array}{c}\text { Race } \\
\text { White }\end{array}$ & 83.06 & 12.50 & 4.44 & 0.035 & 80.21 & 15.51 & 4.28 & 0.284 \\
\hline Ethnic Minority & 75.20 & 22.40 & 2.40 & & 73.62 & 22.09 & 4.29 & \\
\hline $\begin{array}{c}\text { Religion } \\
\text { Christians }\end{array}$ & 83.06 & 13.66 & 3.28 & & 78.99 & 17.63 & 3.36 & \\
\hline Other Religion & 81.08 & 18.92 & 0.00 & 0.512 & 76.09 & 19.57 & 4.35 & 0.968 \\
\hline No Religion & 77.63 & 17.76 & 4.61 & & 76.22 & 18.92 & 4.86 & \\
\hline $\begin{array}{c}\text { Income } \\
\text { Under } \$ \mathbf{5 0 , 0 0 0}\end{array}$ & 80.33 & 18.03 & 1.64 & 0.256 & & 17.36 & 3.47 & 0.717 \\
\hline Above $\$ 50,000$ & 80.56 & 14.68 & 4.76 & & 75.85 & 19.32 & 4.83 & \\
\hline
\end{tabular}

Takyi SA. Relationship between the Demographic Characteristics of Park Users and Park Based User Activities: The Case of Stanley Park and Queen 


\section{Journal of Ecology \& Natural Resources}

\begin{tabular}{|c|c|c|c|c|c|c|c|c|}
\hline $\begin{array}{c}\text { Age } \\
\text { Under 30 }\end{array}$ & 73.64 & 21.82 & 4.55 & & 70.00 & 23.85 & 6.15 & \\
$\mathbf{3 0 - 4 0}$ & 75.96 & 20.19 & 3.85 & 0.009 & 65.75 & 28.77 & 5.48 & 0.000 \\
Over 40 & 89.24 & 7.59 & 2.16 & & 89.19 & 8.78 & 2.03 & \\
\hline
\end{tabular}

Table 4: Relationship between Demographic Characteristics of Park Users \& Playing Active Field Sports.

${ }^{*} \mathrm{H}_{\mathrm{o}}$ : There is no relationship between the demographic characteristics of park users and active field sports

${ }^{*} \mathrm{Ha}$ : There is a relationship between the demographic characteristics of park users and active field sports

\section{Demographic Characteristics of Park Users and the Use of Stanley Park and Queen Elizabeth Park for Active Court Sports}

The chi-square analyses showed a statistically significant relationship between employment, gender, place of origin, income, age and the use of Stanley Park for active court sports $(P \leq 0.05)$. The results indicated that park users who are students, unemployed, retired and seasonally employed are likely to use Stanley Park for active court sports than park users who are full time employed. The statistical analysis showed that $19.02 \%$ of park users who are students, unemployed, retired and seasonally employed sometimes use Stanley Park for active court sports compared to $10.43 \%$ among park users who are full time employed.

In terms of gender, males are more likely to use Stanley Park for active court sports than females. While $18.92 \%$ of males sometimes engage in active court sports on the park, it is $9.39 \%$ among females. Also, $77.96 \%$ of males never use Stanley Park for active court sports while it is $85.64 \%$ among females. Additionally, the survey results indicated that park users who visited Stanley Park from Vancouver are more likely to engage in active court sports than those from outside Canada. The results showed that $6.41 \%$ of park users from Vancouver often engage in active court sports while it is less than $2 \%$ among tourists who came from outside Canada. The study further indicated that park users with higher income are more likely to engage in active court sports on Stanley Park than those with lower income. The results indicated that $4.37 \%$ of park users of Stanley Park who often engage in active court sports earn above $\$ 50,000$ while $3.28 \%$ of the park users earn below $\$ 50,000$ a year. With regard to age, the statistical analysis showed that park users below the age of 30 years are more likely to use Stanley Park for active court sport than park users above the age of 40 years. The survey results showed that Stanley Park users below the age of 30 years who often play active court sports were twice as many as those who were above 40 years.

Statistically, the relationship between gender, place of origin, age and playing active court sports on Queen Elizabeth Park is significant $(\mathrm{P} \leq 0.05)$. Similar to the findings of Stanley Park, park visitors who are males are more likely to use Queen Elizabeth Park for active court sports than females. The statistical analysis indicated that $18.68 \%$ of males often engage in active court sports on Queen Elizabeth Park compared to females (7.83\%). Also, $47.80 \%$ of males never engage in active court sports on Queen Elizabeth Park compared to $73.49 \%$ among females.

Additionally, the place of origin of park users is also an important factor contributing to the use of Queen Elizabeth Park for active court sports. The study indicated that park users from Vancouver are more likely to use Queen Elizabeth Park for active court sports than park users from outside Canada. The visitors of Queen Elizabeth Park who came from Vancouver (15.66\%) play active court sports more often than the tourists who came from outside Canada (3.13\%). Queen Elizabeth Park users from Vancouver who never play active court sports constitute $54.80 \%$. On the other hand, $90.63 \%$ of the park users who came from outside Canada never engage in active court sports.

Unlike Stanley Park users, visitors of Queen Elizabeth Park above the age of 40 years (16.89\%) play active court sports more often than users below the age of 30 years $(10.77 \%)$. However, among the park users who never engage in active court sports, $60.00 \%$ were below the age of 30 years with those above age 40 years constituting $64.19 \%$. The study findings further showed that in as much as the adult population frequently play active court sports, most of the youthful population sometimes engage in active court sports. Finally, the chi-square analysis indicated that statistically, there is no significant relationship between employment, marital status, race, 
religion, income and the use of Queen Elizabeth Park for active court sports $(\mathrm{P}>0.05)$. There is therefore not enough evidence to suggest that the null hypothesis $\left(\mathrm{H}_{\mathrm{o}}\right.$ : there is no relationship between employment, marital status, race, religion, income and the use of Queen
Elizabeth Park for active court sports) is false at $95 \%$ confidence level. Table 5 shows the relationship between demographic characteristics and active court sports such as tennis and basketball.

\begin{tabular}{|c|c|c|c|c|c|c|c|c|}
\hline \multirow[b]{2}{*}{$\begin{array}{l}\text { Demographic } \\
\text { Characteristics }\end{array}$} & \multicolumn{4}{|c|}{ Stanley Park } & \multicolumn{4}{|c|}{ Queen Elizabeth Park } \\
\hline & $\begin{array}{c}\text { Never } \\
(\%)\end{array}$ & $\begin{array}{c}\text { Sometimes } \\
(\%)\end{array}$ & $\begin{array}{c}\text { Often } \\
(\%)\end{array}$ & P-Value & $\begin{array}{c}\text { Never } \\
(\%)\end{array}$ & $\begin{array}{c}\text { Sometimes } \\
(\%)\end{array}$ & $\begin{array}{c}\text { Often } \\
(\%)\end{array}$ & P-Value \\
\hline $\begin{array}{c}\text { Employment } \\
\text { Full Time }\end{array}$ & 85.78 & 10.43 & 3.79 & 0.056 & 57.49 & 28.14 & 14.37 & 0.631 \\
\hline Others & 76.69 & 19.02 & 4.29 & & 62.50 & 25.00 & 12.50 & \\
\hline $\begin{array}{c}\text { Marital Status } \\
\text { Married }\end{array}$ & 86.01 & 11.40 & 2.59 & 0.080 & 63.64 & 25.32 & 11.04 & 0.398 \\
\hline Other & 77.38 & 16.67 & 5.95 & & 57.36 & 27.41 & 15.23 & \\
\hline $\begin{array}{l}\text { Gender } \\
\text { Male }\end{array}$ & 77.96 & 18.82 & 3.23 & 0.029 & 47.80 & 33.52 & 18.68 & 0.000 \\
\hline Female & 85.64 & 9.39 & 4.97 & & 73.49 & 18.67 & 7.83 & \\
\hline $\begin{array}{l}\text { Place of Origin } \\
\text { Vancouver }\end{array}$ & 73.72 & 19.87 & 6.41 & & 54.80 & 29.54 & 15.66 & \\
\hline Within Canada & 86.05 & 10.47 & 3.49 & 0.009 & 72.97 & 21.62 & 5.41 & 0.001 \\
\hline Outside Canada & 89.31 & 9.16 & 1.53 & & 90.63 & 6.25 & 3.13 & \\
\hline $\begin{array}{c}\text { Race } \\
\text { White }\end{array}$ & 84.27 & 12.10 & 3.60 & 0.204 & 65.24 & 22.99 & 11.76 & 0.100 \\
\hline Ethnic Minority & 76.80 & 18.40 & 4.80 & & 53.99 & 30.67 & 15.34 & \\
\hline $\begin{array}{c}\text { Religion } \\
\text { Christians }\end{array}$ & 83.06 & 12.02 & 4.92 & & 61.34 & 23.53 & 15.13 & \\
\hline Other Religion & 78.38 & 18.92 & 2.70 & 0.588 & 54.35 & 32.61 & 13.04 & 0.782 \\
\hline No Religion & 81.58 & 15.79 & 2.63 & & 60.54 & 27.03 & 12.43 & \\
\hline $\begin{array}{c}\text { Income } \\
\text { Under } \$ 50,000\end{array}$ & 76.23 & 20.49 & 3.28 & 0.049 & 63.89 & 23.61 & 12.50 & 0.475 \\
\hline Above $\$ 50,000$ & 84.52 & 11.11 & 4.37 & & 57.49 & 28.50 & 14.01 & \\
\hline $\begin{array}{c}\text { Age } \\
\text { Under } 30\end{array}$ & 74.55 & 18.18 & 7.27 & & 60.00 & 29.23 & 10.77 & \\
\hline $30-40$ & 79.81 & 19.23 & 0.96 & 0.005 & 52.05 & $\begin{array}{l}36.99 \\
18.92\end{array}$ & 10.96 & 0.038 \\
\hline Over 40 & 88.61 & 7.59 & 3.80 & & 64.19 & & 16.89 & \\
\hline
\end{tabular}

Table 5: Relationship between Demographic Characteristics of Park Users \& Playing Active Court Sports

${ }^{*} \mathrm{H}_{\mathrm{o}}$ : There is no relationship between the demographic characteristics of park users and active court sports

*Ha: There is a relationship between the demographic characteristics of park users and active court sports 


\section{Demographic Characteristics of Park Users and Relaxing on Stanley Park and Queen Elizabeth Park}

The research findings indicated that there is a statistically significant relationship between marital status, place of origin and relaxing on Stanley Park $(\mathrm{P} \leq 0.05)$. Therefore, there is enough evidence to suggest that the null hypothesis $\left(\mathrm{H}_{\mathrm{o}}\right.$ : there is no relationship between marital status, place of origin and relaxing on Stanley Park) is false at $95 \%$ confidence level. The survey results indicated that the aggregate of park users who are single, divorced or widowed are more likely to relax on Stanley Park than park users who are married. The study indicated that park users, who are single, divorced or widowed $(29.17 \%)$ relax more often on Stanley Park than park users who are married (19.17\%). Also, among the park users who never relax on Stanley Park, 25\% are single, divorced or widowed while $38.86 \%$ are married.

The statistical analysis further indicated that park users from Vancouver are more likely to relax on Stanley Park than park users from outside Canada. Overall, the visitors of Stanley Park who came from Vancouver $(33.33 \%)$ relax more often on the park than park users who came from outside Canada (19.08\%). Additionally, among the park users who never relax on Stanley Park, 24.36\% were from Vancouver whilst 39.69\% were from outside Canada. Also, the survey results indicated that $42.31 \%$ of park users from Vancouver sometimes relax on Stanley Park compared to $41.22 \%$ of park users from outside Canada.

Furthermore, the statistical test showed that there is no statistically significant relationship between employment, gender, race, religion, income, age and relaxing on Stanley
Park $(\mathrm{P}>0.05)$. Hence, there is not enough evidence to suggest that the null hypothesis $\left(\mathrm{H}_{\mathrm{o}}\right.$ : there is no relationship between employment, gender, race, religion, income, age and relaxing on Stanley Park) is false at 95\% confidence level. The chi-square analysis showed that there is no statistically significant relationship between employment, marital status, gender, place of origin, religion, income, age and relaxing on Queen Elizabeth Park $(\mathrm{P}>0.05)$. Hence, there is not enough evidence to suggest that the null hypothesis $\left(\mathrm{H}_{\mathrm{o}}\right.$ : there is no relationship between employment, marital status, gender, place of origin religion, income, age and relaxing on Queen Elizabeth Park) is false at $95 \%$ confidence level.

The statistical analysis further showed a significant relationship between race and relaxing on Queen Elizabeth Park $(\mathrm{P}>0.05)$. This implies that there is enough evidence to suggest that the null hypothesis $\left(\mathrm{H}_{\mathrm{o}}\right.$ : there is no relationship between race and relaxing on Queen Elizabeth Park) is false at 95\% confidence level. Generally, Whites are more likely to relax on Queen Elizabeth Park than other ethnic minority groups.

The results indicated that park users who are Whites (29.41\%) relax more often on Queen Elizabeth Park than ethnic minority groups such as Blacks and Asians (28.83 $\%$ ). The survey results also showed that $24.60 \%$ of park users who are Whites never relax on Queen Elizabeth Park compared to $35.58 \%$ among the ethnic minority groups. Furthermore, park users who were Whites and those of ethnic minority who sometimes relax on Queen Elizabeth Park constitute $45.99 \%$ and $35.58 \%$ respectively. The bivariate analysis of demographic characteristics of park users and relaxing has been presented in (Table 6).

\begin{tabular}{|c|c|c|c|c|c|c|c|c|}
\hline \multirow{2}{*}{$\begin{array}{c}\text { Demographic } \\
\text { Characteristics }\end{array}$} & $\begin{array}{c}\text { Never } \\
\text { (\%) }\end{array}$ & $\begin{array}{c}\text { Sometimes } \\
\text { (\%) }\end{array}$ & $\begin{array}{c}\text { Often } \\
\text { (\%) }\end{array}$ & P-Value & $\begin{array}{c}\text { Never } \\
\text { (\%) }\end{array}$ & $\begin{array}{c}\text { Qometimes } \\
\text { (\%) }\end{array}$ & $\begin{array}{c}\text { Often } \\
\text { (\%) }\end{array}$ & P-Value \\
\hline $\begin{array}{c}\text { Employment } \\
\text { Full Time }\end{array}$ & 31.75 & 46.92 & 21.33 & 0.311 & 24.55 & 46.71 & 28.74 & 0.061 \\
Others & 33.13 & 39.88 & 26.99 & & 34.78 & 35.87 & 29.35 & \\
\hline $\begin{array}{c}\text { Marital Status } \\
\text { Married }\end{array}$ & 38.86 & 41.97 & 19.17 & 0.009 & 33.77 & 40.26 & 25.97 & 0.317 \\
Other & 25.00 & 45.83 & 29.17 & & 26.90 & 41.62 & 31.47 & \\
\hline $\begin{array}{c}\text { Gender } \\
\text { Male }\end{array}$ & 34.95 & 43.55 & 21.51 & 0.461 & 30.77 & 42.31 & 26.92 & 0.591 \\
Female & 30.39 & 43.09 & 26.52 & & 28.92 & 39.16 & 31.93 & \\
\hline
\end{tabular}

Takyi SA. Relationship between the Demographic Characteristics of Park Users and Park Based User Activities: The Case of Stanley Park and Queen Elizabeth Park. J Ecol \& Nat Resources 2017, 1(2): 000107. 
Journal of Ecology \& Natural Resources

\begin{tabular}{|c|c|c|c|c|c|c|c|c|}
\hline $\begin{array}{l}\text { Place of Origin } \\
\text { Vancouver }\end{array}$ & 24.36 & 42.31 & 33.33 & & 29.54 & 40.93 & 29.54 & \\
\hline Within Canada & 36.05 & 50.00 & 13.95 & 0.002 & 35.14 & 40.54 & 24.32 & 0.946 \\
\hline Outside Canada & 39.69 & 41.22 & 19.08 & & 28.13 & 40.63 & 31.25 & \\
\hline $\begin{array}{c}\text { Race } \\
\text { White }\end{array}$ & 36.29 & 40.73 & 22.98 & 0.077 & 24.60 & 45.99 & 29.41 & 0.054 \\
\hline Ethnic Minority & 24.80 & 49.60 & 25.60 & & 35.58 & 35.58 & 28.83 & \\
\hline $\begin{array}{l}\text { Religion } \\
\text { Christians }\end{array}$ & 33.88 & 41.53 & 24.59 & & 36.97 & 37.82 & 25.21 & \\
\hline Other Religion & 24.32 & 51.35 & 24.32 & 0.776 & 32.61 & 39.13 & 28.26 & 0.259 \\
\hline No Religion & 32.53 & 43.82 & 23.66 & & 24.86 & 43.78 & 31.35 & \\
\hline $\begin{array}{c}\text { Income } \\
\text { Under } \$ \mathbf{5 0 , 0 0 0}\end{array}$ & 29.51 & 40.16 & 30.33 & 0.119 & 31.94 & 37.50 & 30.56 & 0.531 \\
\hline Above $\$ 50,000$ & 33.73 & 45.63 & 20.63 & & 28.50 & 43.48 & 28.02 & \\
\hline $\begin{array}{c}\text { Age } \\
\text { Under } \mathbf{3 0}\end{array}$ & 26.36 & 45.45 & 28.18 & & 26.15 & 43.85 & 30.00 & \\
\hline $30-40$ & 27.88 & 46.15 & 25.96 & 0.142 & 23.29 & $\begin{array}{l}38.36 \\
39.86\end{array}$ & 38.36 & 0.093 \\
\hline Over 40 & 39.24 & 41.14 & 19.62 & & 36.49 & & 23.65 & \\
\hline
\end{tabular}

Table 6: Relationship between Demographic Characteristics of Park Users \& Relaxing

${ }^{*} \mathrm{H}_{\mathrm{o}}$ : There is no relationship between the demographic characteristics of park users and relaxing.

${ }^{*}$ Ha: There is a relationship between the demographic characteristics of park users and relaxing.

\section{Demographic Characteristics and the use of Stanley Park and Queen Elizabeth Park for Sunbathing}

The chi-square analysis indicated that there is a statistically significant relationship between employment, marital status, place of origin, age and the use of Stanley Park for sunbathing $(\mathrm{P} \leq 0.05)$. This shows that there is enough evidence to suggest that the null hypothesis $\left(\mathrm{H}_{\mathrm{o}}\right.$ : there is no relationship between employment, marital status, place of origin, age and the use of Stanley Park for sunbathing) is false at $95 \%$ confidence level. Park users who are full time employed are more likely to use Stanley Park for sunbathing than park users who belong to other employment categories. The park visitors of Stanley Park who are fulltime employed (12.32\%) use the park for sunbathing more often than the aggregate of the other employment categories (4.91\%).

Also, the aggregate of park users who are single, divorced or widowed are more likely to use Stanley Park for sunbathing than park users who are married. The survey results showed that the aggregate of the Stanley Park users who are single, divorced or widowed (11.90\%) tend to engage in sunbathing on Stanley Park more often than park users who are married (7.25\%). Furthermore, $26.79 \%$ of park users who are single, divorced or widowed sometimes use Stanley Park for sunbathing compared to $19.69 \%$ of park users who are married.

In terms of place of origin, park users from Vancouver are more likely to sunbath on Stanley Park than park users from outside Canada. The results of the statistical analysis indicated that park visitors of Stanley Park who came from Vancouver (16.03\%) sunbath more often than those who came from outside Canada (3.82\%). With regard to age, park users below the age of 30 years are more likely to use Stanley Park for sunbathing than park users above the age of 40 years. The study showed that park visitors who were below 30 years of age (11.82\%) use Stanley Park for sunbathing more often than those above the age of 40 years (7.59\%). Also, among the park users who never use Stanley Park for sunbathing 61.82\% 
were below 30 years whilst $76.58 \%$ were above 40 years. The chi-square analysis finally showed that there is no statistically significant relationship between gender, race, religion, income and the use of Stanley Park for sunbathing $(\mathrm{P}>0.05)$. Statistically, there is no significant relationship between gender, place of origin, race, religion, income and the use of Queen Elizabeth Park for sunbathing $(\mathrm{P}>0.05)$. Therefore, there is not enough evidence to suggest that the null hypothesis $\left(\mathrm{H}_{\mathrm{o}}\right.$ : there is no relationship between gender, place of origin, race, religion, income and the use of Queen Elizabeth Park for sunbathing) is false at $95 \%$ confidence level. Furthermore, the chi-square analysis showed a statistically significant relationship between employment, marital status, age and the use of Queen Elizabeth Park for sunbathing $(\mathrm{P} \leq 0.05)$. The research findings indicated that the aggregate of park users such as students, unemployed, retired and seasonally employed (8.70\%) engage in sunbathing on Queen Elizabeth Park more often than the users who are full time employed (6.50\%). However, among the park users who sometimes engage in sunbathing on Queen Elizabeth Park, 34.13\% are park users who fall within other employment categories whilst $16.30 \%$ are full time employed.
With regard to marital status, the aggregate of park visitors who are single, widowed or divorced are more likely to use Queen Elizabeth Park for sunbathing than park users who are married. According to the survey results, the aggregate of park visitors who are single, widowed or divorced $(8.12 \%)$ engage in sunbathing more often than park users who are married (7.14\%). Furthermore, the statistical analysis showed that park users who are under the age of 30years are more likely to use Queen Elizabeth Park for sunbathing than park users who are over the age of 40 years. The study indicated that as many as twice the park users who are under the age of 30 years use Queen Elizabeth Park for sunbathing more often than park visitors above the age of 40 years.

Additionally, the survey results indicated that among the park users who never use Queen Elizabeth Park for sunbathing, $68.85 \%$ were under the age of 30 years whilst $76.35 \%$ were above 40 years. The demographic characteristics and sunbathing have been presented in (Table 7).

\begin{tabular}{|c|c|c|c|c|c|c|c|c|}
\hline \multirow[b]{2}{*}{$\begin{array}{l}\text { Demographic } \\
\text { Characteristics }\end{array}$} & \multicolumn{4}{|c|}{ Stanley Park } & \multicolumn{4}{|c|}{ Queen Elizabeth Park } \\
\hline & $\begin{array}{c}\text { Never } \\
(\%)\end{array}$ & $\begin{array}{c}\text { Sometimes } \\
(\%)\end{array}$ & $\begin{array}{l}\text { Often } \\
\text { (\%) }\end{array}$ & P-Value & $\begin{array}{l}\text { Never } \\
(\%)\end{array}$ & $\begin{array}{c}\text { Sometimes } \\
(\%)\end{array}$ & $\begin{array}{c}\text { Often } \\
(\%)\end{array}$ & P-Value \\
\hline $\begin{array}{l}\text { Employment } \\
\text { Full Time }\end{array}$ & 65.40 & 22.27 & 12.32 & 0.046 & 59.28 & 34.13 & 6.59 & 0.001 \\
\hline Others & 69.94 & 25.15 & 4.91 & & 75.00 & 16.30 & 8.70 & \\
\hline $\begin{array}{l}\text { Marital Status } \\
\text { Married }\end{array}$ & 73.06 & 19.69 & 7.25 & 0.053 & 74.68 & 18.18 & 7.14 & 0.030 \\
\hline Other & 61.31 & 26.79 & 11.90 & & 61.93 & 29.95 & 8.12 & \\
\hline $\begin{array}{l}\text { Gender } \\
\text { Male }\end{array}$ & 67.74 & 22.04 & 10.22 & 0.703 & 65.38 & 26.92 & 7.69 & 0.683 \\
\hline Female & 69.06 & 23.20 & 7.73 & & 69.28 & 22.89 & 7.83 & \\
\hline $\begin{array}{l}\text { Place of Origin } \\
\text { Vancouver }\end{array}$ & 59.62 & 24.36 & 16.03 & & 68.33 & 24.56 & 7.12 & \\
\hline Within Canada & 70.93 & 24.42 & 4.65 & 0.002 & 64.86 & 21.62 & 13.51 & 0.608 \\
\hline Outside Canada & 74.81 & 21.37 & 3.82 & & 62.50 & 31.25 & 6.25 & \\
\hline $\begin{array}{c}\text { Race } \\
\text { White }\end{array}$ & 68.95 & 20.56 & 10.48 & 0.126 & 64.71 & 26.74 & 8.56 & 0.501 \\
\hline Ethnic Minority & 64.80 & 28.80 & 6.40 & & 70.55 & 22.70 & 6.75 & \\
\hline $\begin{array}{c}\text { Religion } \\
\text { Christians }\end{array}$ & 70.49 & 19.13 & 10.38 & 0.207 & 73.11 & 21.85 & 5.04 & 0.440 \\
\hline
\end{tabular}

Takyi SA. Relationship between the Demographic Characteristics of Park Users and Park Based User Activities: The Case of Stanley Park and Queen 


\begin{tabular}{|c|c|c|c|c|c|c|c|c|}
\hline Other Religion & 59.46 & 35.14 & 5.41 & & 67.39 & 26.09 & 6.52 & \\
No Religion & 65.79 & 26.32 & 7.89 & & 63.78 & 26.49 & 9.73 & \\
\hline $\begin{array}{c}\text { Income } \\
\text { Under \$50,000 }\end{array}$ & 60.66 & 30.33 & 9.02 & 0.092 & 66.67 & 22.92 & 10.42 & 0.256 \\
Above \$50,000 & 70.63 & 20.24 & 9.13 & & 68.12 & 26.09 & 5.80 & \\
\hline $\begin{array}{c}\text { Age } \\
\text { Under 30 }\end{array}$ & 61.82 & 26.36 & 11.82 & & 63.85 & 27.69 & 8.46 & \\
$\mathbf{3 0 - 4 0}$ & 59.62 & 31.73 & 8.65 & 0.017 & 56.16 & 30.19 & 13.70 & 0.015 \\
Over 40 & 76.58 & 15.82 & 7.59 & & 76.35 & 19.59 & 4.05 & \\
\hline
\end{tabular}

Table 7: Relationship between Demographic Characteristics of Park Users \& Sunbathing.

${ }^{*} \mathrm{H}_{\mathrm{o}}$ : There is no relationship between the demographic characteristics of park users and sunbathing

*Ha: There is a relationship between the demographic characteristics of park users and sunbathing

\section{Demographic Characteristics and Enjoying Scenery on Stanley and Queen Elizabeth Park}

The study showed that demographic characteristics such as employment, marital status, gender, place of origin, race, religion, income and age affect the enjoyment of scenery on Stanley Park on a minimal level. Statistically, there is no significant relationship between these demographic characteristics and the enjoyment of scenery on Stanley Park $(\mathrm{P}>0.05)$. Therefore, there is not enough evidence to suggest that the null hypothesis $\left(\mathrm{H}_{\mathrm{o}}\right.$ : there is no relationship between demographic characteristics of park users and the enjoyment of scenery on Stanley Park) is false at 95\% confidence level.

Also, the statistical test showed that there is no significant relationship between marital status, gender, place of origin, race, religion, income and the enjoyment of scenery on Queen Elizabeth Park ( $>>0.05)$. However, unlike Stanley Park, there is a statistically significant relationship between employment, age and the enjoyment of scenery on Queen Elizabeth Park $(\mathrm{P} \leq 0.05)$. Thus, there is enough evidence to suggest that the null hypothesis $\left(\mathrm{H}_{\mathrm{o}}\right.$ : there is no relationship between employment, age and the enjoyment of scenery on Queen Elizabeth Park) is false at $95 \%$ confidence level.

The survey results indicated that park users who are full time employed $(37.13 \%)$ enjoy the scenery on Queen Elizabeth Park less often than the aggregate of park visitors who belong to other employment categories (46.20\%). Furthermore, among the park users who never enjoy scenery on Queen Elizabeth Park, $11.38 \%$ were full time employed whilst $18.48 \%$ belonged to the other employment categories. The study further showed that park users above the age of 40 years (47.97\%) enjoy the scenery on Queen Elizabeth Park more often than those below the age of 30 years (33.85\%). The survey results also showed that among the Queen Elizabeth Park users who never enjoy scenery, $20.77 \%$ were below the age of 30 years whilst those above the age of 40 years constituted $9.46 \%$. The summary of demographic characteristics and the enjoyment of scenery have been shown in Table 8.

\begin{tabular}{|c|c|c|c|c|c|c|c|c|}
\hline \multirow{2}{*}{$\begin{array}{c}\text { Demographic } \\
\text { Characteristics }\end{array}$} & $\begin{array}{c}\text { Never } \\
\text { (\%) }\end{array}$ & $\begin{array}{c}\text { Sometimes } \\
(\%)\end{array}$ & $\begin{array}{c}\text { Often } \\
(\%)\end{array}$ & P-Value & $\begin{array}{c}\text { Never } \\
(\%)\end{array}$ & $\begin{array}{c}\text { Sometimes } \\
(\%)\end{array}$ & $\begin{array}{c}\text { Often } \\
(\%)\end{array}$ & P-Value \\
\hline $\begin{array}{c}\text { Employment } \\
\text { Full Time }\end{array}$ & 20.38 & 45.02 & 34.60 & 0.629 & 11.38 & 51.50 & 37.13 & 0.007 \\
$\begin{array}{c}\text { Others } \\
\text { Marital Status } \\
\text { Married }\end{array}$ & 24.54 & 42.94 & 32.52 & & 18.48 & 35.33 & 46.20 & \\
\hline
\end{tabular}

Takyi SA. Relationship between the Demographic Characteristics of Park Users and Park Based User Activities: The Case of Stanley Park and Queen Elizabeth Park. J Ecol \& Nat Resources 2017, 1(2): 000107. 
Journal of Ecology \& Natural Resources

\begin{tabular}{|c|c|c|c|c|c|c|c|c|}
\hline Other & 23.21 & 42.86 & 33.93 & & 17.26 & 43.65 & 39.09 & \\
\hline $\begin{array}{l}\text { Gender } \\
\text { Male }\end{array}$ & 22.58 & 43.01 & 34.41 & 0.989 & 14.84 & 44.51 & 40.66 & 0.858 \\
\hline Female & 22.65 & 43.65 & 33.70 & & 15.66 & 41.57 & 42.77 & \\
\hline $\begin{array}{c}\text { Place of Origin } \\
\text { Vancouver }\end{array}$ & 19.23 & 39.74 & 41.03 & & 16.01 & 40.93 & 43.06 & \\
\hline Within Canada & 22.09 & 44.19 & 33.72 & 0.089 & 16.22 & 45.95 & 37.84 & 0.421 \\
\hline Outside Canada & 25.95 & 48.85 & 25.19 & & 6.25 & 56.25 & 37.50 & \\
\hline $\begin{array}{c}\text { Race } \\
\text { White }\end{array}$ & 22.58 & 44.35 & 33.06 & 0.960 & 11.76 & 47.06 & 41.16 & 0.130 \\
\hline Ethnic Minority & 21.60 & 44.00 & 34.40 & & 18.40 & 38.65 & 42.94 & \\
\hline $\begin{array}{l}\text { Religion } \\
\text { Christians }\end{array}$ & 24.04 & 39.34 & 36.61 & & 17.65 & 41.18 & 41.18 & \\
\hline Other Religion & 21.62 & 45.95 & 32.43 & 0.488 & 10.87 & 43.48 & 45.65 & \\
\hline No Religion & 20.39 & 49.34 & 30.26 & & 14.59 & 43.78 & 41.62 & \\
\hline $\begin{array}{c}\text { Income } \\
\text { Under } \mathbf{\$ 5 0 , 0 0 0}\end{array}$ & 23.77 & 45.90 & 30.33 & 0.625 & 17.36 & 43.75 & 38.89 & 0.502 \\
\hline Above $\$ 50,000$ & 21.43 & 43.25 & 35.32 & & 13.53 & 42.51 & 43.96 & \\
\hline $\begin{array}{c}\text { Age } \\
\text { Under } 30\end{array}$ & 22.73 & 50.00 & 27.27 & & 20.77 & 45.38 & 33.85 & \\
\hline $30-40$ & 18.27 & 45.19 & 36.54 & 0.316 & 16.44 & $\begin{array}{l}39.73 \\
42.57\end{array}$ & 43.84 & 0.046 \\
\hline Over 40 & 24.05 & 39.24 & 36.71 & & 9.46 & & 47.97 & \\
\hline
\end{tabular}

Table 8: Relationship between Demographic Characteristics of Park Users \& Enjoying Scenery.

${ }^{*} \mathrm{H}_{\mathrm{o}}$ : There is no relationship between the demographic characteristics of park users and enjoying scenery

${ }^{*}$ Ha: There is a relationship between the demographic characteristics of park users and enjoying scenery

\section{Discussion and Conclusion}

Researchers such as Field, Scott and Gobster have done extensive studies on assessing the relationship between leisure behaviour and park use [10,23,24]. Field [23], assessed variables that help in explaining the regularity of social behaviour in parks. Scott on the other hand, tested the association between the activities of park users and the time of the day, day of the week and season of the year [24]. The research conducted by Gobster focused on the characteristics of park users [10]. The study showed that minority park users came in family oriented groups compared to park users who are White. Generally, these studies were restricted to the prediction of the urban park user patterns for various demographic characteristic. However, this study assesses the relationship between the demographic characteristics of park users and park based user activities such as biking and jogging.

The statistical analysis indicated that the place of origin of park users is a major contributory factor to park decision making. For example, the statistical analysis showed a statistically significant relationship between place of origin and park activities such as biking, active court sports and relaxing on both Stanley Park and Queen Elizabeth Park $(\mathrm{P} \leq 0.05)$. Generally, park users from Vancouver are more likely to undertake these activities compared to park users from outside Canada.

The study further indicated that there is no statistically significant relationship between the demographic characteristic of park users and engaging in park 
activities such as walking and using public facilities on Stanley Park $(\mathrm{P}>0.05)$. Also, there is a statistically significant relationship between age and park activities such as jogging, rollerblading, active field sports and active court sports on both Stanley Park and Queen Elizabeth Park $(\mathrm{P} \leq 0.05)$. The research findings show a pattern where park activities that require more physical strength are generally dominated by the youthful population. In planning for park development based on the demographic characteristics of park users, there is the need for park researchers and administrators to categorize the use of parks into active and passive park user activities.

The survey results generally showed that active park activities such as jogging and biking are mostly influenced by age and gender with the youthful population dominating in these activities. On the other hand, passive park activity such as enjoying scenery is mostly dominated by the adult population.

Within the city setting, there are various spaces for recreational activities such as biking, playing active court sports and field sports either than in the parks. However, most park users chose Stanley Park and Queen Elizabeth Park for recreation because of their natural setting. The study showed that most park users use Stanley Park and Queen Elizabeth Park for their recreational activities because of ecological benefits such as connection to nature, access to fresh air and aesthetics from the natural environment. This implies that the natural ecological nature of parks serves as a source of attraction to park users.

\section{Acknowledgment}

I want to thank to my doctoral supervisor, Dr. Andrew Seidel for his mentorship and guidance throughout the research process. To my wonderful and hardworking research assistants, Rebecca Delorey and Sameer Sadhir, thank for your support during and after data collection. I appreciate the support of my wife Mrs. Cecilia Animah Takyi and my brother Mr. Augustine Takyi for their advice, emotional support and prayers. My final appreciation goes to my wonderful colleagues and friends Mr. Tristan Johnson, Mr. Jonathan Asante and Dr. Jones Adjei for their inputs and advice. God richly bless you all.

\section{References}

1. Hayward D, Weitzer W (1984) The Public Image of Urban Parks, past amenity, Present Ambivalence, Uncertain future, Urban Ecology 8(3): 243-268.
2. Bish RL, Clemens EG (2008) Local Government in British Columbia, Richmond, Union of British Columbia Municipalities, $4^{\text {th }}$ Edition.

3. Garvin A, Berens G (1997) Urban parks and open space. Washington D.C. Urban Land Institute and Trust for Public Land.

4. Gress M (2009) Examining Park Space and Demographics Using GIS within Minnesota and Saint Paul, Minnesota Vol. 11, Papers in Resource Analysis, 15pp, Saint Mary's University of Minnesota Central Services Press, Winona, MN, Retrieved.

5. Chiesura A (2003) The Role of Urban Parks for the Sustainable City, Landscape and Urban Planning 68: 129-138.

6. Kitchen JW, Hendon WS (1967) Land Values Adjacent to an Urban Neighbourhood Park, Land Economics 43(3): 357-360.

7. Burgess J, Carolyn MH, Melanie L (1988) People, Parks and the Urban Green: A Study of Popular Meanings and Values for Open Spaces in the City, Urban Studies 25(6): 455-473.

8. Thompson CW (2002) Urban Open Space in the 21st Century, Landscape and Urban Planning 60(2): 59-72.

9. Byrne J, Sipe N (2010) Green and Open Space Planning for Urban Consolidation - A Review of the Literature and Best Practice, Urban Research Program, Issues Paper 11, Brisbane, Griffith University.

10. Gobster PH (2002) Managing urban parks for a racially and ethnically diverse clientele, Leisure Sciences: An Interdisciplinary Journal 24(2): 143-159.

11. Home R, Bauer N, Hunziker M (2007) Constructing Urban Green Spaces: An Application of Kelly's Repertory Grid, Tourism Review 62(3): 47-52.

12. Bowler DE, Ali-Buyung L, Knight TM, Pullin AS (2010) Urban greening to Cool Towns and Cities: A Systematic Review of the Empirical Evidence, Landscape and Urban Planning 97(3): 147-155.

13. Alvey AA (2006) Promoting and Preserving Biodiversity in the Urban Forest, Urban Forestry \& Urban Greening 5 (4): 195-201. 
14. Ozguuner, Kendel HD (2006) Public Attitudes towards Naturalistics Versus Designed Landscapes in the City of Sheffield (UK), Landscape and Urban Planning 74: 139-157.

15. Nowak DJ, Dwyer JF (2007) Understanding the Benefits and Costs of Urban Forest Ecosystems, In Urban and Community Forestry in the Northeast 2546.

16. Willis GB (2005) Cognitive Interviewing: A Tool for Improving Questionnaire Design. Thousand Oaks, CA: Sage.

17. Dowling R (2010) Power, Subjectivity, and Ethics in Qualitative Research, In Qualitative Research Methods in Human Geography, Ed. Iain Hay. Oxford: Oxford University Press, pp: 26-39.

18. Bradburn NM, Seymour S, Brian W (2004) Asking Questions: The Definitive Guide to Questionnaire Design for Market Research, Political Polls, and Social and Health Questionnaires, John Wiley \& Sons.

19. Vaske JJ (2008) Survey Research and Analysis: Applications in Parks, Recreation and Human Dimensions, State College, Venture Publishing Inc.
20. Payne LL (2011) Resource Guide for Community Survey Projects, Office of Recreation \& Park Resources, Champaign, University of Illinois.

21. Mowen AJ, Trauntvein NE, Graefe AR, Son JS (2012) The Influence of Visitor Characteristics on State Park Physical Activity Levels, Journal of Park and Recreation Administration 30(2): 19-40.

22. Cohen DA, Mckenzie TL, Sehgal A, Williamson S, Golineli D, et al. (2007) Contribution of Public Parks to Physical Activity, Am J Public Health 97(3): 509514.

23. Field DR (2000) Social groups and parks: Leisure behavior in time and space, Journal of Leisure Research 32(1): 27-31.

24. Scott D (1997) Exploring time patterns in people's use of A Metropolitan Park District, Leisure Sciences 19 (3): 159-174.

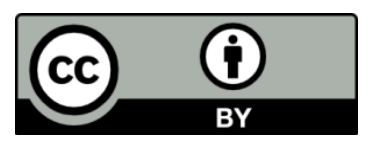

Takyi SA. Relationship between the Demographic Characteristics of Park Users and Park Based User Activities: The Case of Stanley Park and Queen Elizabeth Park. J Ecol \& Nat Resources 2017, 1(2): 000107. 